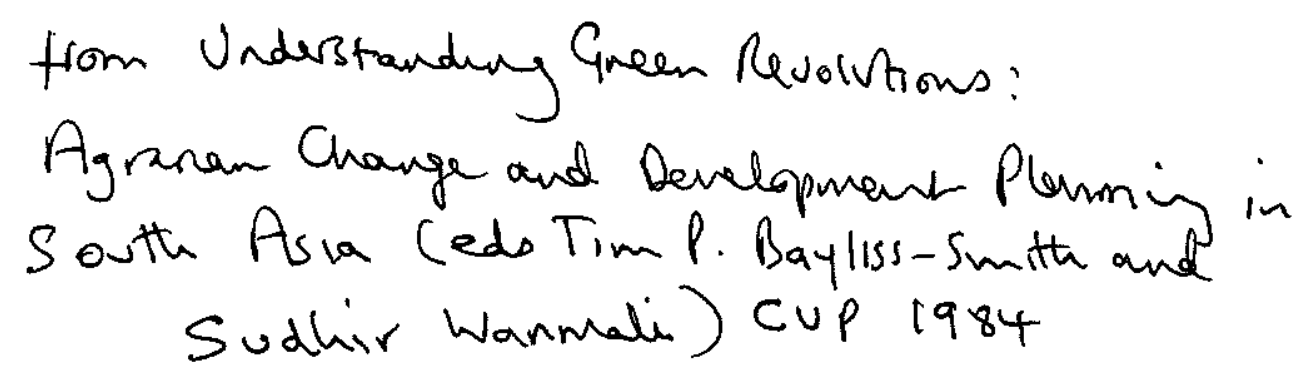

\title{
Beyond the Green Revolution: a selective essay
}

ROBERT CHAMBERS

\begin{abstract}
'The Green Revolution' is used so loosely to cover so much technological, agrarian and social change, in so many countries and zones, with so many ecological and social differences, that generalisations are precarious and subject to exceptions. Even if we focus on India, and on small farmers and labourers, as this essay does, almost every statement still deserves a paragraph of qualification. Even if the Green Revolution is narrowed to changes linked with new agricultural technology, taking the rapid rise in wheat production in Northwest India in the later 1960s as a classic case, there is still much room for debate and disagreement.
\end{abstract}

\section{Views of the Green Revolution}

Discussion is not made easier by the passionate assertion to which the Green Revolution has given rise. Little attention has been paid to the psychology and sociology of ignorance, prejudice and the selective use of evidence in analysing the Green Revolution; yet one obvious feature, with which it is salutary to start, has been the polarisation between those who have taken views which are positive and optimistic, and those whose views have been negative and pessimistic.

Those who have been positive and optimistic have included biological scientists involved in creating the new technologies. In the early days of the Green Revolution some of them saw an enormous potential for increased production. They were fired with enthusiasm and faith, excited at the way in which the new dwarf wheats and rices shifted yield potentials to new high levels. Attention was concentrated on geographical areas which were well endowed with irrigation water and infrastructure, most notably the Punjab and Haryana in India where the new seed-fertiliser-water technology was exploited very quickly. The spectacular trebling of wheat production in the Indian Punjab during the decade of the 1960 s encouraged optimism. As the Green Revolution spread to other crops, some saw the prospect of banishing hunger from the world.

Those who took negative and pessimistic views included social scientists concerned with political economy, and with who gained and who lost from the Green Revolution. Many studies showed that the new technologies were 
captured by and benefited the rural elites and those in the more favoured regions. ${ }^{1}$ Social scientists' attention was drawn especially to the new highyielding varieties of foodgrains, which they found being planted, fertilised, and protected by pesticides, most where there was irrigation, and most on the fields of the larger and more prosperous farmers. Biplab Dasgupta concluded from his study of the Green Revolution in India that some of the major social and economic consequences of the new technology included 'proletarianization of the peasantry and a consequent increase in the number and proportion of landless households, growing concentration of land and assets in fewer hands, and widening disparity between the rich and poor households ...' (1977, p. 372). Evidence was accumulated of tenants displaced by landlords as agriculture became more profitable, of landless labourers deprived of employment through mechanisation, and of women whose postharvest employment was destroyed as hand-processing was replaced by mechanical methods. In their negative assessments, some social scientists saw the Green Revolution sharpening social tensions, and some spoke of it turning red.

\section{The positive optimists}

With hindsight, errors can be seen in both points of view. The positive optimists made two main mistakes. The first was to suppose that the dramatic rises in wheat output of the early Green Revolution in Northwestern India, and the high-yielding potential of early rice HYVs like IR8, could be realised on a much wider scale. This belief was sustained by misleading statistics for the adoption of HYVs elsewhere. Agricultural extension staff were given ambitious targets, and reported these achieved when the reality lagged far behind: in part of South India, the area under HYVs according to official reports was over three times the actual (Chinnappa, 1977, p. 98) and in part of Bangladesh five times (pers. comm., Hugh Brammer). Moreover, as is now recognised, wheat in Northwest India was a special case. Agricultural production there had been held back because the application of nitrogenous fertiliser led to lodging, a problem which the short-strawed HYVs overcame at a stroke. A generally uniform environment and fertile soil, good groundwater, good infrastructure, land consolidation, and commercially-minded farmers, provided the preconditions for rapid adoption of the HYV package once it was available. But elsewhere, and with other crops, conditions were not as favourable. For rice, in particular, there were many problems of environment, water control, pests, and diseases which inhibited rapid spread (Farmer, 1979; Barker \& Pal, 1979).

The second major error of the positive optimists was to see poverty as a problem of food production. Technical scientists and macro-economists have frequently fallen into this error. Calculations are made of world or country 
food requirements, and of per capita food production. Targets for food production are set, with the assumption that if the food is there, people will be able to eat it. But as Amartya Sen (1981) and others have shown, malnutrition is much less the result of lack of food grown, and much more the result of poor people lacking the means to obtain it; in short, a problem of poverty more than a problem of food supply.

\section{The negative pessimists}

For their part, the negative pessimists also made two main errors. Both concern the selection and analysis of evidence. In the first place, attention was drawn to geographical areas and to incidents which generated and sustained conclusions about the Green Revolution turning red. As John Harriss (1977) pointed out for India, published studies were biased towards the betterirrigated districts selected for the Intensive Agricultural District Programme (IADP), especially around the Punjab Agricultural University in Ludhiana, leaving vast areas of central India largely unreported. In concluding his own carefully documented study of a village in North Arcot District in Tamil Nadu, he notes (1982, p. 300) that "widely expressed expectations of "social change" as a consequence of the "green revolution", have generally been simplistic', and attributes this in part to these expectations being based on areas in which the agrarian structures have been dominated by landlords and where movements of agrarian protest may be more likely. In his village, and in contrast to some common views, he found the intensification of agriculture increasing the demand for labour, probably raising agricultural wages, and strengthening not weakening the relations of dependency between poor peasants and labourers, and rich farmers.

There are, of course, the usual dangers of over-generalising from one village or one incident. Others have fallen, perhaps willingly, into this trap with the notorious Kilvenmanai incident in Thanjavur District in Tamil Nadu in 1968 when 43 Harijans were killed. The incident involved larger landowners, local labourers, and immigrant labourers. Repeatedly quoted by non-Indian observers (e.g. Wharton, 1969; Frankel, 1971; Vallianatos, 1976), Kilvenmanai was interpreted as a sign that the Green Revolution was turning red; yet as Harriss notes, there had been a history of such conflicts in Thanjavur. But those who were looking for evidence of this sort seized on the incident, and reinforced each other by repetition. In the early 1980 s both the reality and the interpretations have shifted: violence against Harijans and landless labourers appears more common now but both less noticed than it deserves and less interpreted to be a result of technological change.

Second, there was a tendency towards a rather narrow analysis of cause. Changes which occurred were sometimes attributed to the new technology 
and its monopoly by rural elites to the neglect of other causes, such as population pressures on resources, subdivision of land on inheritance, and contingencies which forced land sales. The counterfactual tended to be overlooked - what would have happened without the new technology. A further problem faced by negative assessments which found the poorer people worse off (e.g. Rajaraman, 1977) was population movements. Technological change could certainly displace labour through capital-intensive methods; but it could also draw in labour, as it did in a South Indian village, Kalpattu, where a good aquifer, numerous electric pumpsets, and cultivation round the year attracted immigration and was associated with higher wage rates than nearby (Chambers \& Harriss, 1977). Similarly, it can be asked for the Indian Punjab whether the slight declines in consumption levels of the poorest three deciles identified by Rajaraman may not have been associated with inmigration from other, poorer areas (eastern Uttar Pradesh and Bihar) where people would have been much worse off if they had not moved. As much care is needed in negative as in positive assessments of technological change.

Finally, most observers, of whatever discipline, were misled into giving excessive prominence to the new varieties of foodgrain as against other conditions and changes. The summary of findings of the major study by UNRISD (1974) was entitled The Social and Economic Implications of the Introduction of the new Varieties of Foodgrains. Lester Brown wrote Seeds of Change (1970), Andrew Pearse Seeds of Plenty, Seeds of Want (1980), and P.R. Mooney Seeds of the Earth (1980). The Nobel Prize went to Norman Borlaug who was involved in the seed-breeding work with wheat and maize. Seedbreeders rode high, and the seeds were the most dramatic new input. Now it is true that seed-breeding, and also the conservation of genetic resources, are crucial activities; and it is also vital to look ahead, as M.S. Swaminathan (1981) has done, to see how breeding priorities should be modified for future conditions and needs. But in many past and future changes in agriculture, new varieties are only one element, and may sometimes not feature at all. Earlier, the rapid spread of the use of chemical fertilisers, especially before 1973 , led some to speak of a fertiliser rather than a seed revolution. But above all, in the Indian subcontinent at least, it is water that has been the least recognised yet most important factor in rural agricultural change. The irrigated potential said to have been created in India has more than trebled since independence: in 1947 it was 19 million hectares, and in 1981 some 60 million. Irrigation has raised yields, reduced risks, provided preconditions for using high-yielding packages, generated employment, and made wages higher than they would have been. But water is an odd subject which somehow slips between the disciplines. Seeds can be created, displayed, and held in the hand; water is dispersed and elusive and slides out of sight. Only in the 1980s is its true significance in rural development in South Asia beginning to be recognised. 


\section{Pluralist realism}

The lesson to be drawn is that caution is needed in assessments of the social effects of technological change. Unless interpretations are empirically based, tested for selective perception, and open to qualification, they are liable to serious error. More broadly, the history of ideas about rural poverty and rural development in the 1960 s and 1970 s is sobering. So many insights have become available so late; so many professions and professionals have been so wrong so much of the time, and yet so sure they were right. There have been many false turnings and blind alleys: the earlier orthodoxy that elevated industrialisation and neglected agriculture in development strategies; the belief that two-thirds of the rural people in the third world were malnourished, whereas a better understanding of nutrition and more careful analysis suggest much lower figures (Sukhatme, 1977; Edmundson, 1980; Seckler, 1980; Poleman, 1981); the belief that malnutrition was primarily a protein problem, not, as now generally held, largely a problem of calorie deficiency; the belief that village-level post-harvest losses were very high, of the order of 10 to $40 \%$ (with $30 \%$ often loosely stated), not as now established by meticulous research, almost always less than $10 \%$ (e.g. $6.9 \%$ for post-harvest rice operations in Bangladesh (Greeley, 1982)); the belief that failure to adopt new agricultural practices was the result of cultural constraints and ignorance, not, as now recognised, much more a function of rational risk-aversion and defects in the practices recommended; and the belief that modern scientific knowledge was inherently superior to what rural people know, whereas the richness and validity of indigenous technical knowledge is now much better recognised (IDS, 1979; Brokensha et al., 1980). The list could be lengthened with other insights such as urban bias (Lipton, 1977) and seasonal dimensions to rural poverty, but the point is made. Professionals have often been wrong.

The most obvious implication of these changes in development beliefs is that whatever is believed now may in its turn be proved wrong. A much humbler attitude is called for from the development professions. Perhaps the best that one can do at any one time is to try to summarise current clusterings of ideas, recognising that they will be superseded.

One such clustering in the early 1980 s could be described as pluralist realism in approaches to rural poverty. This entails taking insights freely from different disciplines and ideologies. One normative version of a pluralist contemporary view might run as follows. Development should be about the poorer people, and their livelihoods, basic needs, and quality of life. Development policy which focusses on this must emphasise command over resources and the ability to make effective demands. Those who are assetless must be enabled to obtain more employment and more assets both for their own production and as buffers against contingencies. But most redistributive 
reform of existing resources, notably land, has failed. Moreover, rural elites tend to capture programmes intended for those who are poorer. Professionals concerned with rural development should therefore concentrate more of their attention on resources which local elites are less likely or able to capture, and to which the poorer people have a realistic chance of establishing lasting rights.

This requires a new sort of analysis and search for which three guiding principles can be suggested. The first is to seek changes in which the poor can gain while those who are less poor do not lose and may even gain overall. For the landless an example is the introduction of year-round irrigation which gives them more work and which may generate labour shortages and raise daily wages. Others include physical and biological research and development which is based on and fits the needs and resources of the poor. The second is to concentrate attention on common property resources of land, water, grassland, forests, fisheries and so on, and explore ways in which their productivity can be increased and the poor can control and benefit from that increase. The third is to examine the scope and concerns of existing disciplines, professions and departments, and ask what potentials in rural development they systematically overlook. Programmes based on their traditional scope and concerns have already been implemented, and have already all too often been captured by rural elites. But in the gaps which they have left, there may be major potentials yet to be realised, and from which the poor might disproportionately benefit. Where all three of these guiding principles apply, the opportunities for this approach may be greatest.

\section{Resources for the rural poor}

Analysis on these lines can indicate many potentials, some of them not yet well recognised, to help small farmers and landless labourers to gain command over more resources. Five illustrations can suffice:

\section{(i) Water reform for canal irrigation}

On canal irrigation systems in India, as also elsewhere in South and Southeast Asia and in North Africa (Egypt and Sudan), there is a disciplinary, professional and departmental gap between the major irrigation works which are the concern of civil engineers and Departments of Irrigation, and crops on farmers fields which are the concern of agriculturalists and soil scientists and of Departments of Agriculture and of Soil Conservation. Analysis and procedures for scheduling and distributing water on main irrigation systems, down to the outlets where the water passes into field channels controlled by farmers, receive little professional attention (Wade \& Chambers, 1980). They are almost totally ignored in the training of those who are to control 
water distribution. A major textbook on irrigation engineering devotes less than two pages out of 563 to alternatives in water scheduling, and a manual of the American Society of Civil Engineers on the operation and maintenance of irrigation and drainage systems has only some three pages on the same subject (Singh, 1979; ASCE, 1980). On many canal irrigation systems, little control is exercised over water distribution, issues at the top-ends are permissive, and tail-enders are deprived. A crop-cutting study on the Mahanadi Reservoir Project in India, which irrigates $180000 \mathrm{ha}$, found a gradient in paddy rice yields from $1541 \mathrm{~kg} / \mathrm{ha}$ at the top to only $218 \mathrm{~kg} / \mathrm{ha}$ at the tail (Lenton, 1982, citing information from Water and Power Consultancy Services (India) Ltd). An examination of the tail-end deprivation on canal irrigation in Sri Lanka has found a concentration of wealth among topenders, who harvest bigger and more reliable crops, and who can invest in tractors, businesses and education for their children; while tail-enders are poorer, with lower and less reliable yields, lower returns to labour, less access to services, and less political influence (Moore et al., forthcoming).

The need and opportunity here are to develop and use methods for the diagnostic analysis of live irrigation systems, for monitoring their performance, and for more equitable and productive scheduling of water issues. Action research is one promising approach (Early, 1980; Lenton, 1980; Bottrall, 1981b). The work of IRRI in the Philippines has shown that circumstances can exist in which main system water redistribution can be reorganised so that all farmers gain: in their pioneering work on the Penaranda River Irrigation System, Wickham and Valera (1979, p. 74) reported production increases following improved distribution of $8 \%$ at the top, $32-62 \%$ in the middle, and $137 \%$ at the tail. Flooding, waterlogging and salinity in the headreaches of canal irrigation systems are sufficiently common to suggest that 'non-zero-sum' redistribution, in which headreach farmers gain in the long run even if not in the immediate short run, may be quite a common possibility. The main beneficiaries will often be relatively deprived people - tail-enders who have suffered from an inadequate, unpredictable and untimely water supply, and who consequently have had little incentive to adopt higher-yielding practices. moreover, the production increases from water reform should be very substantial. Following his extensive study of irrigation in South, Southeast and East Asia, Anthony Bottrall concluded (1981a, p. 24) that there was 'an immense opportunity for improvements in the performance of irrigation projects through management reform', and that in the rice-growing areas of South and Southeast Asia on a very conservative assumption of $20 \%$ increases in production, this would mean production increase of 30 million tons of paddy or 20 million tons of rice. And many of those producing the rice would be farmers previously deprived of a good irrigation water supply. Unlike much of the Green Revolution, this would achieve production and equity goals at the same time. 


\section{(ii) Land reform when canal irrigation starts}

At the time when new canal irrigation is introduced into an area, all departments are heavily engaged. Civil engineers are deeply involved in construction; land acquisition for canals and other works is a major preoccupation; and agriculturalists and agricultural extension staff are concerned with changes in cropping patterns. For those who have land which receives water, this is usually a time of dramatic increase in the value of land. The passing opportunity which this presents for the redistribution of land is often overlooked. There is a period as irrigation arrives when land could be redistributed without anyone losing from the land-reform-plus-irrigation package. The scale of this opportunity is enormous but it only comes once and must be seized when it arrives. Sites for canal irrigation development will run out. India, Mexico and Sri Lanka, for example, all propose to double their irrigated area by the end of the century. For canal irrigation in India, this means moving from the current potential said to have been created of perhaps 28-29 million hectares to close to the ultimate potential of 58.5 million hectares (Seckler, 1981, quoting IARI, 1980). Even with the shortfalls which can be expected, this will present a passing opportunity for a land-cum-irrigation reform to settle millions of landless families.

\section{(iii) Access to common property groundwater}

In South Asia, groundwater is the greatest remaining common resource which is subject to individual appropriation. Bangladesh has perhaps the finest underground aquifer in the world, but irrigates only some $18 \%$ of its potential for a second (post-monsoon or boro) crop. India has achieved a phenomenal explosion in lift irrigation, with electric and diesel pumpsets rising from 430000 in $1960-61$ to about 7.2 million in 1980-81 (Charlu \& Dutt, 1982, p. 93). Estimates of unexploited groundwater potential in India range from a high of 70 per cent of annual renewable recharge not yet utilised in 1980 (Sangal, 1980) to a low of 39 per cent remaining in 1982 (Government sources which estimated 24.5 million hectares of land already covered out of a potential of 40 million). In either case the remaining potential is enormous.

The question usually addressed is how fast this process can take place. Perhaps more important in the long run is the other question, of who will benefit from the process (IDS, 1980). About 200 million rural people, part of the greatest concentration of rural misery in the world, live in Uttar Pradesh, Bihar and West Bengal. In Uttar Pradesh in 1976-77, 86\% of all holdings, comprising almost half of the agricultural land, were reported to be less than 2 hectares in size, with a long-term trend towards even smaller holdings (Agricultural Census, 1976-77, cited in Kalra, 1981). The standard irrigation pumps are 5 horsepower, and sometimes 3 horsepower. Between these rela- 
tively large pumps on the one hand, and lift by human or animal power on the other, there lies a power gap. The issue here is whether tens of millions of very small farmers can be provided with a scale and type of lift technology which will fit their land and other resources, or whether alternatively there are feasible ways in which they can organise and combine to obtain and share larger-scale pumps.

A lift technology appropriate for very small farmers whose land lies above good groundwater has received little attention. Any such technology would have to be cheap, maintainable, and based on a renewable or easily accessible energy source. There have been numerous experiments with solat power (Halcrow, 1981), wind power, biogas, steam engines, and producer gas. Producer gas, generated by the partial combustion of carbonaceous material has the advantage of being a renewable energy source which can be obtained from agricultural wastes on the farm, and so under the farmers' direct control, unlike diesel or electricity (Pathak et al., 1981). But again and again, those developing new energy sources and pump systems think conventionally at too large a scale for the majority of farmers. An exception has been Stephen Allison who has designed photovoltaic solar systems precisely for small farmers. While the price of photovoltaic solar systems for lift irrigation are still high, reported technological breakthroughs suggest that it may be only a matter of years before there are sharp reductions in cost and solar pumping begins to spread. Producer gas or solar or both may well be major power sources of the future for lift irrigation. The question is whether very small farmers will be able to benefit. The answer to that question depends on many factors, including scale, cost and marketing. It is at least possible that power and pumping units could be so designed that they filled the power gap and met the needs of millions of small farmers in India and Bangladesh who at present cannot irrigate.

\section{(iv) Rights to common property land and forest}

Overwhelmingly, attention in India and elsewhere is directed towards agricultural lands which are private property. Statistical services, government departments, research institutes, and social scientists concentrate on the farm sector and agricultural production. In India, the impression is sometimes given that agricultural production is the only rural production that matters. Yet India has some 100 million hectares of forest and common property land (i.e. reserve forests, protected forests, panchayat land, village land, and so on - see Farmer, 1974), while the 143 million hectares of agricultural land receive almost all the attention. ${ }^{2}$

The potential of non-agricultural land is almost universally underestimated. Six reasons go far in explaining this. First, many of them are inaccessible and rarely visited or seen; communications are concentrated in the areas 
of agricultural production. Second, being subject to the tragedy of the commons, they appear more barren than they are. One estimate is that $70 \%$ of such lands in India are already degraded (pers. comm., Deep Joshi). Third, forestry has long gestation periods and so does not attract those who look for quick returns. Fourth, forest dwellers and users of common lands tend to be low status people like tribals in central India, or some nomadic pastoralists. Fifth, corrupt officials, politicians and contractors have enormous financial interests in illicit exploitation of forests and in drawing as little attention as possible to this. Finally, the management problems of communal resources are intractable and offer no easy solutions.

To take a positive view, the opportunity presented by India's nonagricultural lands is enormous. The potential value of their produce has risen sharply with growing shortages of firewood and with rising prices for timber, and can be expected to rise yet further. Their potential has also risen with the introduction of new species and new methods, of which Leucaena (NAS, 1977 ) is the most spectacular. In the early 1980s, millions of poor people who derive their livelihoods from the forest are in danger of losing out to contractors and to a custodial Forest Department. But there are also grounds for hope. Social forestry has become a widespread movement. Although it usually means growing trees on private land, once again benefitting the larger farmers, or on roadsides, canal banks and other public places without determining who shall benefit, there are examples where the intention is that the poorer should gain. In Chitrakoot (on the Uttar Pradesh-Madhya Pradesh border), landless tribal families have been allocated common property land on which they grow Leucaena, with the aim of their being able to support cattle subsequently. The difficulties must not, however, be underestimated. Profound hostility exists between many poor forest-users and the Forest Department. A major re-orientation of both is a precondition for any largescale movement to enable the poor forest-users to be proprietors and partners in forest development.

\section{(v) Priorities in agricultural research}

The obvious big gains from agricultural research have been in production. The best known were the breakthroughs from changing the plant architecture of major cereals and raising their yield responses to nitrogen. But later work on pest and disease resistance and robustness has been also very important, as the successes of IR20 in Indonesia and IR36 in the Philippines have shown. For the future there may be breakthroughs through genetic engineering, tissue culture, and other techniques, perhaps leading to a nitrogen-fixing wheat or maize. Other gains may come from shifts of priority to pay more attention to crop residues (straw, bran, the roots of the plant), rooting systems, ease of processing and cooking, yield stability, and biological nitrogen- 
fixation, to name but some. But increased productivity is the easier problem. Increases in consumption, by the poor, must come from enhancing their command over food supplies, whether through self-provisioning or through exchange. The more difficult problem is to orient agricultural research to benefit the smaller farmers and the landless, by improving their incomes, food supplies and security through increased production and employment.

This can be done in a multiplicity of ways which require only a little imagination to see. Unfortunately this is sometimes lacking in negative social scientists and positive biological scientists alike. Examples include: effort directed towards the crops and animals of the poor rather than those of the better-off; reducing risks for small farmers, especially those in marginal environments; improving the farming systems of small farmers to produce more, and of larger farmers not only to produce more but also to require more labour over more of the year; breeding stable seeds which reproduce faithfully rather than hybrids which must be purchased again each year; biological nitrogenfixation to reduce dependence on the market for chemical nitrogen; selecting for ease of domestic processing and cooking, reducing the work burden on women; seed-breeding of crops like sorghum for calories for the poor rather than protein to fatten the animals of the rich. The list could be lengthened. Many, many shifts of research towards the interests of the poorer rural people are possible.

Such shifts have already been made. A lead has come from the Consultative Group for International Agricultural Research which funds and oversees IRRI and the other international research centres. It has not done all that it might have done, but it has gone further than most national agricultural research systems. For over a decade it has been moving towards greater attention to marginal environments and small and poor farmers. ICRISAT (the International Crops Research Institute for the Semi-Arid Tropics) was established in 1972 to concentrate on neglected subsistence crops-sorghum, pearl millet, chickpea, and pigeon-pea. Work on cassava (manioc, tapioca), especially that of the IITA (International Institute of Tropical Agriculture) in Nigeria and of CIAT (Centro Internacional de Agricultura Tropica) in Colombia has led to sharp increases in yield and improvements in disease resistance; and cassava is the staple and fall-back food of last resort of large numbers of people in Africa, Asia and Latin America. IRRI's research priorities have been moved to give much more attention to rice which is grown under rainfed, rather than controlled irrigated, conditions. Farming systems analysis in the international centres and elsewhere, involving agricultural economists and sociologists as well as agricultural scientists, has made progress towards better understanding of small farming systems. ${ }^{3}$ In the unirrigated semi-arid tropics ICRISAT has been unable to achieve dramatic crop-specific breakthroughs like CIMMYT's with wheat and IRRI's with rice, but it has used farming systems analysis and a farming systems approach 
to identify feasible synergistic combinations of improved varieties, soil and water management, and fertiliser applications with mixed cropping (see, for example, Ryan et al., 1982).

These changes of method and priority have been slow to spread in national agricultural research systems. In India, a farming systems approach is little practised outside ICRISAT. Agricultural research remains largely croporiented, and geared towards the resources and interests of larger and more commercial farmers. The needs and crops of the poor remain relatively neglected. Biases are stacked against them: researchers are drawn to work on commercial crops, on commercial processing, on high-input technology, on single rather than mixed cropping or farming systems, on what directly concerns men (land preparation, economic returns to cash crops) rather than women (subsistence crops, weeding, processing, storing quality, and cooking). Disciplinary specialisation, preferences for tidy research on research stations and in laboratories, departmentalism, hierarchy, and a failure to recognise small farmers as fellow professionals - all these militate against a good understanding of small farmers' needs and opportunities.

One under-researched gap is the linkages between crops, animals, fodder and trees. These fall between disciplines and between departments. Foresters are concerned mainly with trees in forests, not on farmers' fields. Agriculturalists are concerned with field crops, not tree crops. Animal specialists are concerned with animal health more than nutrition. In consequence, the potential of tree fodders such as Leucaena (NAS, 1977) was long to be recognised. In India, it is perhaps not surprising that it was a nongovernment organisation free of departmental rigidities, the Bharatiya AgroIndustries Foundation near Pune, that carried out much of the early practical research on Leucaena. Another under-researched gap is the potential for tree crops to act as biological pumps in areas which are waterlogged from irrigation, turning a problem (too much water) into an opportunity (to fix sunlight, gain biomass, and perhaps use it for producer gas to pump more water mechanically for irrigation).

Finally, so-called 'high' agricultural technology presents opportunities. These may be overlooked because of the fashion for appropriate technology. But however sensible appropriate technology may be, quite new approaches, if carefully designed and introduced, may also fit the needs of the poor. Nutrient film technique is one case. It has been developed in the industrialised world and it depends on a reliable year-round water supply and on the purchase of nutrients, but it has the advantage of requiring very little land. Moreover, in tropical conditions of high insolation it can produce very high yields of biomass. In Chitrakoot in India, annual fodder yields of 700 tonnes/ha (280 tons per acre) have been reported with Napier grass. Landless families have been 'settled' on 0.06 ha (one seventh of an acre) each. It is envisaged that one acre ( $0.4 \mathrm{ha})$ will support 20 head of cattle, pro- 
vided some concentrates are added to their diet (pers. comm. R. Madhavan). Many questions have to be asked about this approach. But it is a healthy challenge to conventional thinking, opening up new possibilities for agricultural livelihoods for the landless, in which both fertile land and rainfall are of minor significance.

\section{A professional revolution}

For all the positive aspects of these opportunities, there are no easy solutions to rural poverty. In some respects, both physically and socially, it is becoming more intractable. Physically, the degradation of natural resources continues to diminish the productive base, especially of soil (see e.g. Kanwar, 1982), while populations continue to increase, with India's expected to rise from 700 million in 1982 to one billion by the year 2000 . Socially, family acquisitiveness appears to have hardened. One opinion for India is that

The socio-political situation is perhaps in some ways far less favourable to economic growth as a means of eradication of mass poverty than it was during the early years of independence... The newly formed, tenaciously covetous and aggressive rural middle class presents more formidable and organised resistance to the planning process than did the landed aristocracy whom it has replaced. (Joshi, 1982)

It becomes more important than ever to seek strategies which are realistic and feasible in spite of physical and social constraints.

One way forward is clearer than it was a decade ago. The modes of analysis and skills of social scientists and of physical and biological scientists are complementary. In choosing what to do, either is very limited without the other. Social scientists alone drive themselves into negative pessimism; and one suspects that those who are most negative and pessimistic have hardly ever met a physical or biological scientist who is involved in trying to change things. And physical and biological scientists on their own neglect who will gain and who will lose from their work. Some even give the impression that they have never asked themselves that question, let alone having exercised imagination to try to change the social effects of what they do. But when physical and biological scientists work together with social scientists, the outcome can be a sort of practical political economy of technological change: and analysis of power and interests, and of who stands to gain and who to lose, which can both inform and change styles and priorities in technical research, influence the way in which programmes are designed and implemented, and improve the chances that the poorer people will benefit. Destructive negativism in the social sciences, and naive optimism in the technical sciences, are luxuries which the poor rural people cannot afford.

For the 1980s and 1990s, a major focus is, therefore, professional reorientation for both social and technical scientists, and the evolution of better ways 
in which they can work together. One approach is for them to adopt additional, common methods of analysis. By being additional, these may not conflict unduly with their professional norms; by being common, they provide a framework for mutual learning. One example is seasonal analysis, in which the concerns of each discipline as they affect poorer people are traced and analysed through time, and inter-disciplinary linkages (between food intake, energy output, health, nutritional status, child care, migration, social relations, cash and food reserves, food prices, indebtedness, etc.) are identified, and actions designed to make the worst times of the year less bad for those who are more vulnerable (Chambers, Longhurst \& Pacey, 1981). Another is to learn from rural people. Since they do not distinguish disciplinary domains, their systems of knowledge and their categories provide frames within which professionals can relate in new ways. Their knowledge of many matters which touch them closely is, moreover, often far superior to that of outsiders. Yet another is to invest the technology, crops and animals of the poor with higher professional status. This entails continuing to shift the balance from the exotic to the indigenous, from the marketed cash crop to the subsistence crop, from large animals to small, from what concerns men to what concerns women. The shifts required are not absolute, but matters of degree, and they are already occurring. For many professionals they present an opportunity. It is precisely past neglect and present ignorance of the things which are important to the poor that presents room for improvement, and that permits 'discovery' by scientists and the prestige that goes with it. If more of them recognise this, the next generation of biological technology should better fit the resources of small farmers and the needs of the landless and make things better for them than they would otherwise have been.

Social scientists will be quick to point out, correctly, that many of the broader social and political changes which are needed can only occur with more effective demand by the poor themselves. The trap here is that while poor, they cannot demand; and while they cannot demand, they remain poor. Analysed at a general level, this becomes a logic of despair. But in practice there are many points of entry. Not only in India, poor rural people are organising and being helped to organise more and more. The personal level, too, is a major starting point. Through personal changes in the values and action of professionals, many shifts are possible - in research priorities, in resource allocations, in criteria for professional advancement, in policies of journal editors, in university and training curricula; and many of these, as they affect the rural poor in the South, have changed in the past two decades, not least in the citadels of professionalism in the North.

To speak of revolutions suggests radical and often improbable change; and outside a few specially favoured geographical areas, the Green Revolution deserved the question mark which B.H. Farmer (1977) gave it. Many of the changes which can realistically benefit the rural poor are not revolutionary in 
the normal sense, but require small and painstaking steps taken resolutely in a consistent direction. The revolution needed for this is professional: a turning round to face the other way, to put first the resources, technology, crops and animals of the poor and give them more priority. As more and more professionals make this reversal, so more and more of their work will be directed to enable the poor better to help themselves. Nor should this reversal be dismissed lightly as an unrealistic hope. It has already been made by some and it can be made by many more. Enough professionals have already turned around to show that this may be less a naive hope than a new realism. A direct attack on rural poverty through a widespread revolution, green or red, is improbable, and would as in the past have mixed effects. A better life for disadvantaged rural people may be more feasibly sought through a different sort of change: through quiet personal revolutions in the perceptions, values and choices of processionals concerned with research, technology and action for rural development.

NOTES

1. See, for example, Frankel (1971), Byres (1972), UNRISD (1974), Palmer (1976), Dasgupta (1977), Hameed et al. (1977), Pearse (1980).

2. These figures are taken from Vohra (1980), but the statistics are unreliable. Swaminathan $(1980$, p. 3) points out that the forest area of India is 66 million hectares in agricultural statistics, compared with about 75 million hectares in forestry statistics. Officially there are about 16 million hectares of 'culturable waste' in India, but after an extensive review Benny Farmer (1974, p. 31) concluded that 'a large proportion of "culturable waste" is very poor land indeed, naturally infertile and often further impoverished by over-grazing and soil erosion'. Farmer considered that to make any precise estimate of the utilisable proportion of all uncultivated lands was then (1974, p. 34) impossible, in the absence of suitable land resource surveys (cf. Govt. of India, 1968).

3. See, for example, the publications of the Farming Systems Research Group, Michigan State University, and Gilbert, Norman and Winch (1980).

\section{REFERENCES}

ASCE (1981). Operation and Maintenance of Irrigation and Drainage Systems, ASCE Manuals and Reports on Engineering Practice No. 57, American Society of Civil Engineers, New York

Barker, R. \& Pal, T.K. (1979). Barriers to increased rice production in Eastern India. IRRI Research Paper Series No. 25, International Rice Research Institute, Manila

Bottrall, A. (1981a). Comparative Study of the Management and Organization of Imigation Projects, World Bank Staff Working Paper No. 458, World Bank, Washington DC 
(1981b). Improving canal management: the role of evaluation and action research. Water Supply and Management, 5, 67-79

Brokensha, D.W., Warren, D.M. \& Werner, O. (1980). Indigenous Knowledge Systems and Development, University Press of America, Lanham, Maryland

Byres, T.J. (1972). The dialectic of India's Green Revolution. South Asian Review, $5,99-116$

Brown, Lester R. (1970). Seeds of Change-The Green Revolution and Development in the 1970s. Praeger, New York

Chambers, R. \& Harriss, J. (1977). Comparing twelve South Indian villages: in search of practical theory. In B.H. Farmer (ed.), Green Revolution? Macmillan, London, pp. 301-22

Chambers, R., Longhurst, R. \& Pacey, A. (1981). Seasonal Dimensions to Rural Poverty. Frances Pinter, London

Charlu, T.G.K. \& Dutt, D.K. (1982). Ground Water Development in India, Rural Electrification Corporation, New Delhi

Chinnappa, B.N. (1977). Adoption of the new technology in North Arcot District. In B.H. Farmer (ed.), Green Revolution? Macmillan, London, pp. 92-123

Dasgupta, Biplab (1977). Agrarian Change and the New Technology in India. United Nations Research Institute for Social Development, Geneva

Early, A.C. (1980). An approach to solving irrigation system management problems. In IRRI, Report of a Planning Workshop on Irrigation Water Management, International Rice Research Institute, Manila, pp. 83-113

Edmundson, W. (1980). Adaptation to undernutrition: how much food does Man need? Social Science and Medicine, 14D, 119-26

Farmer, B.H. (1974). Agricultural Colonization in India since Independence. Oxford University Press, London, for Royal Institute of International Affairs

(ed.) (1977). Green Revolution? Technology and Change in Rice-growing Areas of Tamil Nadu and Sri Lanka. Macmillan, London

(1979). The 'Green Revolution' in South Asian ricefields: environment and production. Journal of Development Studies, 15, 304-19

Frankel, F. (1971). India's Green Revolution: Economic Gains and Political Costs. Princeton University Press

Gilbert, E.H., Norman, D.W. \& Winch, F.E. (1980). Farming Systems Research: a critical appraisal, MSU Rural Development Paper No. 6, Department of Agricultural Economics, Michigan State University, East Lansing

Govt. of India (1968). Report of the Waste Land Survey (Technical) Committee. Govt. Press, Shillong

Greeley, M. (1982). Pinpointing post-harvest losses. Ceres, 15 (1), no. 85, 30-7

Halcrow (1981). Small-Scale Solar-Powered Irrigation Pumping Systems Technical and Economic Review. Sir William Halcrow \& Partners, with Intermediate Technology Development Group, London

Hameed, N.D.S. et al. (1977). Rice Revolution in Sri Lanka. United Nations Research Institute for Social Development, Geneva

Harriss, J. (1977). Bias in perception of agrarian change in India. In B.H. Farmer (ed.), Green Revolution? Macmillan, London, pp. 30-6

(1982). Capitalism and Peasant Farming: agrarian structure and ideology in 
Northern Tamil Nadu. Oxford University Press, Bombay, Delhi, Calcutta, Madras

IARI (1980). Irrigation Development in India - Tasks for the Future. Indian Agricultural Research Institute, Pusa, Delhi

IDS (1979). Rural Development: Whose Knowledge Counts? IDS Bulletin, 10 (2). Institute of Development Studies, University of Sussex

(1980). Who gets a last rural resource? The potential and challenge of lift irrigation for the rural poor. IDS Discussion Paper No. 156, by IDS Study Seminar 88, Institute of Development Studies, University of Sussex

Joshi, P.C. (1982). Institutional dimensions in agricultural planning. Kurukshetra, $30(9), 16$ March

Kalra, B.R. (1981). Size and distribution of operational holdings. Kurukshetra, 29 (23), 1-15 September

Kanwar, J.S. (1982). Managing Soil Resources to Meet the Challenges to Mankind. Presidential Address, 12th International Congress of Soil Science, New Delhi, $8-16$ February

Lenton, R. (1980). Field experimentation and generalization in irrigation development and management. Paper presented at 17 th Annual Convention of Indian Society of Agricultural Engineers, Indian Agricultural Research Institute, New Delhi

(1982). Management tools for improving irrigation performance. Ford Foundation, New Delhi

Lipton, M. (1977). Why Poor People Stay Poor: Urban Bias in World Development. Temple Smith, London

Mooney, P.R. (1980). Seeds of the Earth: A Private or Public Resource? Inter Pares, Ottawa, for Canadian Council for International Co-operation and International Coalition for Development Action, London

Moore, M.P., Abeyratne, F., Amerakoon, R. \& Farrington, J. (forthcoming). Space and the generation of socio-economic inequality on Sri Lanka's irrigation schemes. Marga (Marga Institute, Colombo)

NAS (1977). Letucaena: Promising Forage and Tree Crop for the Tropics. National Academy of Sciences, Washington, DC

Palmer, I. (1976). The New Rice in Asia: Conclusions from Four Country Studies. United Nations Research Institute for Social Development, Geneva

Pathak, B.S., Rogers, P. \& Pahoja, M.H. (1981). Producer Gas Systems and Agricultural Applications: Proceedings of a Workshop held in New Delhi, December 5, 1981. Indian Society of Agricultural Engineers, New Delhi

Pearse, A. (1980). Seeds of Plenty, Seeds of Want: Social and Economic Implications of the Green Revolution. Clarendon Press, Oxford

Poleman, T.T. (1981). A reappraisal of the extent of world hunger. Food Policy, 6, 4 November, $236-52$

Rajaraman, Indira (1977). Growth and poverty in rural areas of the Indian State of Punjab. In Poverty and Landlessness in Rural Asia. International Labour Office, Geneva, pp. 61-74

Ryan, J.G., Virmani, S.M. \& Swindale, L.D. (1982). Potentials and challenges from deep black soils in relatively dependable rainfall regions of India. Paper 
presented at the Seminar on Innovative Technologies for Integrated Rural Development, New Delhi

Sangal, S.P. (1980). Groundwater resources and development in India. Paper to Seminar on Development and Management of Ground Water Resources, Indian Association of Geohydrologists, Vigyan Bhawan, New Delhi

Seckler, D. (1980). 'Malnutrition': an intellectual odyssey. Paper presented at the Annual Meeting of the Western Agricultural Economic Association, Las Cruses, New Mexico

(1981). The new era in irrigation management in India. Ford Foundation, New Delhi (mimeo)

Sen, Amartya (1981). Poverty and Famines: An Essay on Entitlement and Deprivation. Clarendon Press, Oxford

Singh, Bharat (1979). Fundamentals of Irrigation Engineering, 6th edn. Nem Chand \& Bros., Roorkee, India

Sukhatme, P.V. (1977). Malnutrition and poverty. 9th Lal Bahadur Shastri Memorial Lecture, Indian Agricultural Research Institute, New Delhi

Swaminathan, M.S. (1980). Indian forestry at the crossroads. In Report of the Seminar on Community Forestry, Ranchi Consortium for Community Forestry, Ranchi, Bihar, pp, 1-8

(1981). Plant breeding in preparation for the 21st century. Meghnad Saha Medal Lecture

UNRISD (1974). The Social and Economic Implications of Large-Scale Introduction of New Varieties of Foodgrain. United Nations Research Institute for Social Development, Geneva

Vohra, B.B. (1980). A Policy for Land and Water. Sardar Patel Memorial Lectures, Department of Environment, Govt. of India

Wade, R. \& Chambers, R. (1980). Managing the main system: canal irrigation's blind spot. Economic and Political Weekly, 15, 39, Review of Agriculture, September, A-107-12

Wickham, T.H. \& Valera, A. (1979). Practices and accountability for better water management. In D.C. Taylor \& T.H. Wickham (eds.), Irrigation Policy and the Management of Irrigation Systems in Southeast Asia, The Agricultural Development Council, Inc.,Bangkok, pp. 61-75 